\title{
Antibiotic use in animal feed and its impact on human health
}

\author{
Mary D. Barton \\ School of Pharmacy and Medical Sciences, University of South Australia, GPO Box 2471, \\ Adelaide, South Australia 5001, Australia
}

\begin{abstract}
Antibiotic resistance in bacteria that cause disease in man is an issue of major concern. Although misuse of antibiotics in human medicine is the principal cause of the problem, antibiotic-resistant bacteria originating in animals are contributory factors, with some types of resistance in some species of bacteria. Antibiotics are added to animal feeds to treat and prevent infections and to improve growth and production. Until recently, the major concerns about incorporation of antibiotics in animal feeds related to antibiotic residues in products from treated animals. Although, in 1969, the Swann (1969) report drew attention to the potential for antibiotic-resistant bacteria to spread from treated animals via the food chain, there was little response until the detection of vancomycin-resistant enterococci in animals fed a related glycopeptide, avoparcin. Subsequently, attention started to focus on the issue and other examples of transfer of resistant bacteria through the food chain, such as enterococci resistant to quinupristin-dalfopristin or to everninomicin, fluoroquinoloneresistant campylobacters and multiresistant Escherichia coli, and salmonella such as Salmonella typhimurium DT104. Reviews and committees in many countries have highlighted the need for better control of licensing of antibiotics, and codes for prudent use of antibiotics by veterinary practitioners and farmers. The continued use of antibiotic growth promoters has been questioned and there is a need to ensure that antibiotics important in human medicine are not used therapeutically or prophylactically in animals.
\end{abstract}

\section{Drug resistance: Antibiotics: Animal feeds}

\begin{abstract}
Introduction
Over the last three decades there has been concern over the problem of antibiotic resistance in human pathogens, leading to recent widespread debate about these problems. The debate has become more intense over the past 5 years or so. Much of the concern has been directed against the use of antibiotics in animals, with particular focus on antibiotic growth promotors. This
\end{abstract}


concern has led to the publication of a number of reports from committees and groups in Europe, the UK, the USA and Australia (Commission on Antimicrobial Feed Additives, 1997; World Health Organization, 1997, 1998; Health Council of The Netherlands, 1998; House of Lords, 1998; Joint Expert Technical Advisory Committee on Antibiotic Resistance, 1999; Ministry of Agriculture, Fisheries and Food, 1998). These reports all emphasised the need for greater control over the use of antibiotics in veterinary medicine and animal husbandry, but there have also been reports suggesting that there is insufficient scientific evidence (Congress of the United States, 1995; Heidelberg Appeal Nederland Foundation 1998; National Research Council, Institute of Medicine, 1998; General Accounting Office, 1999) to support the link between the use of antibiotics in animals and antibiotic resistance in human pathogens. Some reports pointed out that most of the antibiotic-resistance problems in human medicine stem from overuse or from inadequate controls in human medicine. None the less, evidence is mounting that antibiotic-resistant enteric bacteria (for example, Escherichia coli, salmonella, campylobacter and enterococci) can transfer from animals to man via the food chain or by direct contact, leading to the establishment of a community reservoir of resistance genes (van den Bogaard \& Stobberingh, 1999).

\section{Use of antibiotics in animals}

Antibiotics are used largely for three purposes in animals: therapeutic use to treat sick animals; prophylactic use to prevent infection in animals; as growth promoters to improve feed utilisation and production. In general, therapeutic treatment involves treatment of individual animals over a short period with doses of antibiotic exceeding the minimal inhibitory concentration of the known or suspected pathogen. Sometimes, with intensively-farmed animals, therapeutic treatment is delivered by feed or drinking water; however, this treatment can be of doubtful efficacy in some situations, as sick animals often do not drink or eat. Prophylactic treatment again involves moderate to high doses of antibiotic, often given in feed or water for a defined period to a group of animals. Antibiotics used as growth promoters tend to be given in feed at subtherapeutic levels over extended periods to entire herds and flocks, and are available for purchase over the counter by feed manufacturers and farmers. It is important to note that subtherapeutic levels generally still exceed the minimal inhibitory concentration of enteric organisms such as Clostridium perfringens and Enterococcus spp. (van den Bogaard \& Stobberingh, 1999).

Concern about use of antibiotics in animals and the possible impact on human health covers two major issues: the antibiotic agents that are used; the way in which they are used. There is a view that antibiotics that are important in human medicine should not be used therapeutically in food-producing animals, particularly for mass medication. Prophylactic use presents a problem on two grounds: the antibiotic agents used; the lack of definition of what is the appropriate duration of prophylactic use. Growth-promotant use is probably the area of highest concern, as some of the antibiotics used are now regarded as compromising the efficacy of some key human antibiotics and the duration of treatment may be for the whole life of the treated animals.

\section{Regulatory controls}

Controls vary from country to country. For example, in Australia there are three points of control of antibiotic use in animals. First, all importations are controlled by a permit system (no 
antibiotics are produced in Australia). Second, at the registration level, there are strict regulatory guidelines over which antibiotics can be used in food-producing animals. Since 1970, antibiotics intended for animal use have been assessed for their potential to compromise human health. As a result, fluoroquinolones, amphenicols, colistin and gentamicin have not been registered for use in food-producing animals because of concerns about antibiotic resistance, and the registration of carbadox was withdrawn in the late 1980s and of nitrofurans in 1992 because of concerns about carcinogenicity (Joint Expert Technical Advisory Committee on Antibiotic Resistance, 1999). Finally, there is control-of-use legislation that restricts antibiotics registered for therapeutic or prophylactic use to registered veterinary surgeons, but allows overthe-counter sales to farmers or stock-feed companies of products registered for use as growth promoters.

Agricultural use of antibiotics in the USA and Canada is also regulated. There are three categories of use: as feed antibiotics; as over-the-counter drugs; as veterinary prescription drugs. Feed antibiotics include antibiotics used as growth promotants and those used for subtherapeutic (including prophylactic and some growth-promotant use) and therapeutic purposes (Prescott, 1997). Feed antibiotics are licensed for specific uses such as for meat chickens or young pigs or calves or feedlot cattle. In the USA preregistration assessment specifically addresses human health issues relating to antibiotic resistance in enteric coliforms, salmonella excretion and increased resistance in salmonella, increased virulence and pathogenicity of bacteria, animal disease that is difficult to treat, and residues and risk of hypersensitivity in consumers (Sundlof et al. 1997). In Canada, the risk of development of antibiotic resistance is not assessed at this stage (Joint Expert Technical Advisory Committee on Antibiotic Resistance, 1999).

In the UK and other EU countries, antibiotics are authorised as either veterinary medicinal products or zootechnical feed additives. Veterinary medicinal products and growth promoters are subject to assessment for safety, including residues (veterinary medicines) and the risk of emergence of antibiotic resistance, cross-resistance to therapeutic antibiotics and selection for transferable resistance (both veterinary medicines and growth promoters; Rutter, 1997). Other European countries outside the EU have their own regulations.

China has regulated the use of antibiotics in animal feeds since 1989 and only non-medical antibiotics are permitted as feed additives. Antibiotics used include monensin, salinomycin, destomycin, bacitracin, colistin, kitasamycin, enramycin and virginiamycin. However, in practice, other antibiotics such as tetracyclines are used and the mycelial by-products from the production of antibiotics are incorporated into animal feeds (Jin, 1997). Russia also restricts feed antibiotics to non-medical drugs; bacitracin, grizin, flavomycin and virginiamycin are registered for use in this way (Panin et al. 1997).

\section{Growth promoters}

Antibiotics used for growth-promotant purposes constitute a large proportion of the total antibiotic usage, but the scale of the problem is difficult to estimate since there is little published information on the overall quantities of antibiotics used in animals or human subjects. In Australia import statistics for the years 1992-3 to 1996-7 show that 55.8\% of antibiotics imported were for use in stock feed, $36.4 \%$ for human use and $7.8 \%$ for veterinary use (Joint Expert Technical Advisory Committee on Antibiotic Resistance, 1999). Prescott (1997) reported that $40 \%$ of antibiotic production in the USA was for use in stock feeds, including 55$60 \%$ of penicillin G and tetracycline production. European Federation of Animal Health (1998) 
Table 1. Comparison of glycopeptide (vancomycin and avoparcin) use in man and animals

\begin{tabular}{lccl}
\hline & \multicolumn{3}{c}{ Glycopeptide $(\mathrm{kg})$} \\
\cline { 2 - 4 } Country and time period & Vancomycin & Avoparcin & Reference \\
\hline Denmark, 1994 & 24 & 24000 & Wegener (1998) \\
Austria, 1992-1996 & 582 & 62642 & Witte (1998) \\
USA, 1996 & 11200 & 0 & Wegener (1998) \\
Australia*, 1992-3 to 1996-7 & 643.1 & 10029.8 & JETACAR (1999) \\
\hline
\end{tabular}

JETACAR, Joint Expert Technical Advisory Committee on Antibiotic Resistance.

${ }^{*}$ Recorded as glycopeptides for human and stock feed use rather than as separate antibiotics.

reported that a 2-month survey in Europe had indicated that of $10493 \mathrm{t}$ antibiotic, $52 \%$ was for medical use, $33 \%$ for veterinary use and $15 \%$ for growth-promotant use. Unfortunately, the definitions of veterinary and growth-promotant use were not given. Some specific data are available for the glycopeptides (see Table 1), showing that more glycopeptides (principally avoparcin) are used in animals than are used in man (vancomycin and teicoplanin).

The chemistry and characteristics of growth promotants registered for use in Europe have been reviewed recently (van den Bogaard \& Stobberingh, 1999).

\section{History of the use of growth-promotant antibiotics}

The growth-promotant effect of low levels of antibiotics in animal feeds was first described in the late 1940s when chickens fed fermentation waste from tetracycline production grew more rapidly than controls (Stokestad \& Jukes, 1950). Over the ensuing 50 years the production-

Table 2. Summary of antibiotics registered for use as growth promotants in Australia, the EU and the USA (adapted from World Health Organization, 1997; Joint Expert Technical Advisory Committee on Antibiotic Resistance, 1998)

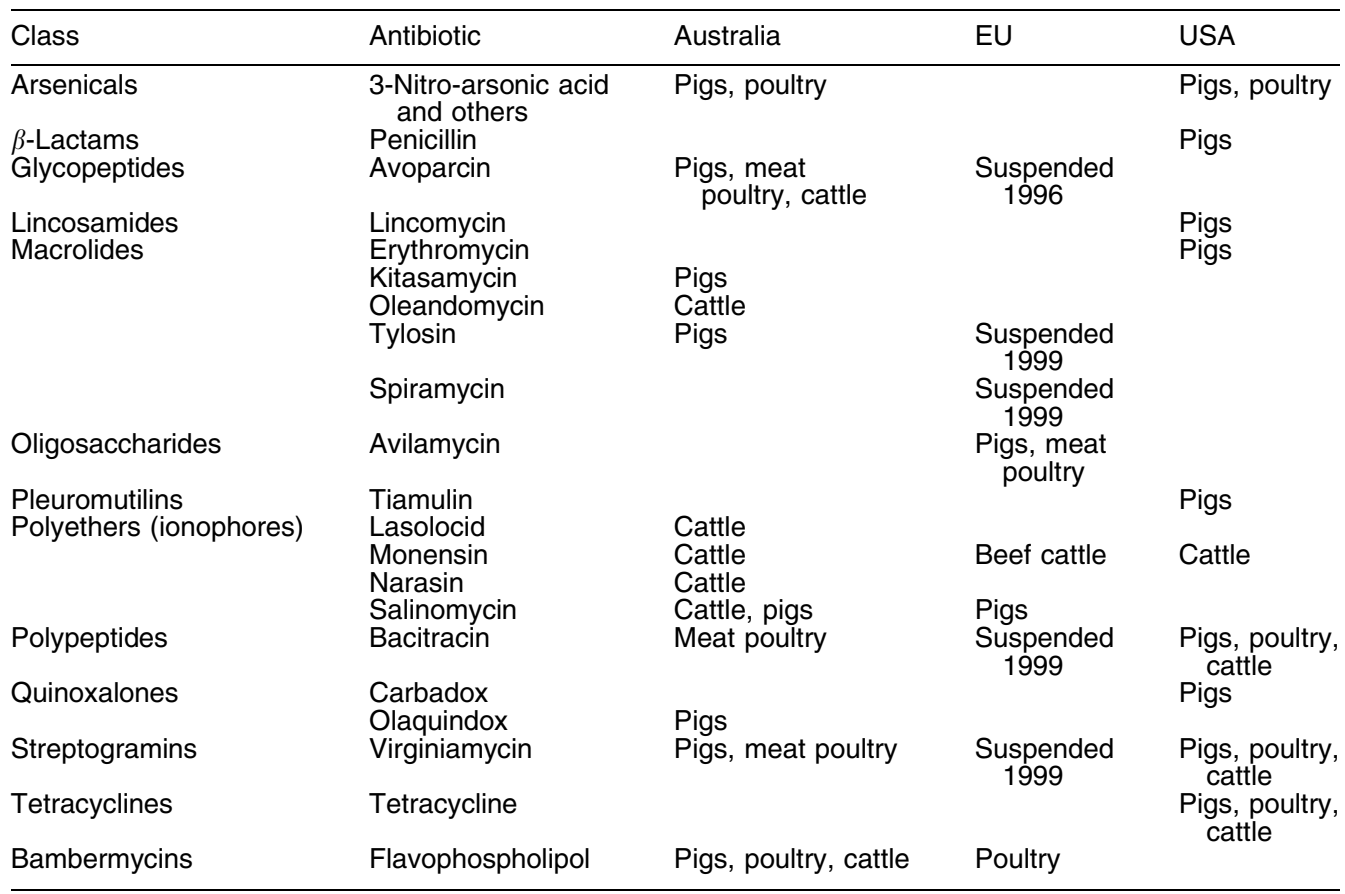


enhancing effects of feeding subtherapeutic levels of a wide range of antibiotics has been described. In this time, the use of growth-promotant antibiotics became entrenched in animal production, particularly in the intensive livestock industries.

Table 2 indicates the growth-promotant antibiotics registered for use in Europe, the USA and Australia. A much wider range is used in the USA than in Australia or Europe. To some extent, this factor reflects the response to the first enquiry into the impact of antibiotic use of animals on human health, the Swann Report (Swann, 1969), and to subsequent investigations in Europe.

The Swann Committee was established in response to concerns about the emergence in the 1960s of transferable antibiotic resistance in human pathogens of animal origin (salmonella) and the possibility of transfer of this resistance to other human enteric pathogens such as $E$. coli and shigella. The committee's report (Swann, 1969) concluded that there was probably a hazard to human health from feeding subtherapeutic levels of antibiotics to food-producing animals. They recommended that antibiotics for use in animal feeds should be restricted to those with little or no therapeutic application in man or animals and which would not impair the efficacy of therapeutic antibiotics because of cross-resistance. In response to the report, a number of countries (including the UK, European countries and Australia) removed penicillin and tetracyclines, at that time the most widely used growth promotants, from the approved list. Interestingly, the USA did not respond in this way because the Food and Drug Administration was unable to demonstrate a threat to public health (Feinman, 1998; see Table 2). In countries conforming to the Swann Report recommendations, other antibiotics rapidly filled the gap.

In parallel with the development of growth promotants in classes of antibiotics at that time of no interest in human medicine, lack of adequate controls on antibiotic use in medical and hospital practice in many countries led to the emergence of antibiotic-resistance problems such as those caused by methicillin-resistant Staphylococcus aureus (MRSA). This factor has prompted interest in the use of antibiotics previously discarded because of lack of suitable systemic formulations (vancomyin) or in classes not used previously in human medicine (virginiamycin, a streptogramin; avilamycin, an orthosomycin). Unfortunately, these antibiotics represent some of the most widely used post-Swann growth promoters.

Despite a steady stream of papers reporting antibiotic resistance in bacterial isolates from animals fed antibiotic-medicated feeds, there was little response from health or industry authorities until 1986 when the Swedish Parliament imposed a ban on antibacterial growth promoters (Commission on Antimicrobial Feed Additives, 1997). There was an initial increase in the therapeutic use of antibiotics, but this situation corrected itself as improvements occurred in animal husbandry, feed formulation and on-farm hygiene (Wierup, 1997). When Sweden joined the EU in 1995, it received derogation from certain EU rules applying to restrictions on antibiotic use in animals until 1 January 1999. This action led to much debate and attempts by other European authorities to refute Swedish claims of reduced antibiotic use on Swedish farms (Viaene, 1997a,b,c). The opponents claimed that the total quantity of antibiotics used in Sweden did not decline because more antibiotics were used therapeutically to treat diseases that had previously been prevented by the use of subtherapeutic levels of antibiotics in feed. The Swedish stance received support from Denmark in 1995, when the detection of vancomycinresistant enterococci (VRE) in pigs and poultry that had been fed avoparcin-medicated feed was reported (Danish Veterinary Laboratory, 1995). Denmark responded by banning the use of avoparcin as a growth promotant in 1995 and Germany followed suit in 1996. Although expert panels such as Scientific Committee for Animal Nutrition (1996) argued that there was insufficient scientific evidence to support such bans, the use of avoparcin was banned in EU countries from 1 April 1997, pending further work. Subsequently other growth promotants were 
scrutinised and, although Scientific Committee for Animal Nutrition (1998a,b) again questioned the adequacy of scientific evidence, the use for virginiamycin, tylosin phosphate, spiramycin and zinc bacitracin was banned in the EU from 1 January 1999, on the basis of the precautionary principle. It could be argued that the ban was put in place to alleviate political concerns, rather than on the basis of scientific evidence.

\section{Mode of action of growth-promotant antibiotics}

The mode of action of antibiotic growth promotants is not known (Commission on Antimicrobial Feed Additives, 1997). Most of the growth promotants are active against Grampositive organisms (Table 3). However, the concentrations used are lower than therapeutic levels, although they may exceed the minimal inhibitory concentration for the Gram-positive intestinal bacteria. The agents are assumed to exert their effect by acting on the intestinal microflora to cause a range of beneficial changes: causing lethal or sublethal damage to pathogens; causing a reduction in the production of bacterial toxins; reducing bacterial utilisation of essential nutrients; allowing increased synthesis of vitamins and other growth factors; improving the absorption of nutrients by reducing the thickness of the intestinal epithelium; reducing intestinal mucosa epithelial cell turnover and reducing intestinal motility (Prescott \& Baggot, 1993). It seems that the addition of growth promotants to feed rations alters intestinal characteristics so that they more closely resemble those seen in germ-free animals (Commission on Antimicrobial Feed Additives, 1997). It is clear that, in many cases, the effects are more noticeable in sick animals and animals housed under conditions of poor hygiene (Prescott \& Baggot, 1993). There are also age-related effects, with younger animals showing a greater response to growth promotants than older animals.

\section{Benefits of growth promoters in animal husbandry}

Antibiotic growth promoters are given primarily to improve productivity and enhance economic returns to farmers (Taylor, 1999). Improvements on growth rate and feed conversion in

Table 3. Antibacterial activity of growth promotant antibiotics

\begin{tabular}{|c|c|c|}
\hline Class of antibiotic & Commonly used growth promotants & Mode of action \\
\hline Arsenicals & 3-Nitro-arsonic acid & DNA effects? \\
\hline Glycopeptides & Avoparcin & Gram-positive cell wall synthesis \\
\hline Lincosamides & Lincomycin & $\begin{array}{l}\text { Inhibit protein synthesis in Gram-positive } \\
\text { bacteria }\end{array}$ \\
\hline Macrolides & $\begin{array}{l}\text { Erythromycin, tylosin, kitasamycin, } \\
\text { oleandomycin, spiramycin }\end{array}$ & $\begin{array}{l}\text { Inhibit protein synthesis, principally in } \\
\text { Gram-positive bacteria }\end{array}$ \\
\hline Oligosaccharides & Avilamycin & $\begin{array}{l}\text { Inhibit protein synthesis in Gram-positive } \\
\text { bacteria }\end{array}$ \\
\hline Pleuromutilins & Tiamulin & As for macrolides \\
\hline Polyethers & Monensin, lasolocid, narasin, salinomycin & $\begin{array}{l}\text { Affect bacterial cell permeability; active } \\
\text { against Gram-positive bacteria }\end{array}$ \\
\hline Polypeptides & Bacitracin & Gram-positive cell-wall synthesis \\
\hline Quinoxalones & Carbadox, olaquindox & $\begin{array}{l}\text { Inhibit bacterial DNA synthesis and } \\
\text { denature pre-existing DNA; active } \\
\text { against anaerobes }\end{array}$ \\
\hline Streptogramins & Virginiamycin & $\begin{array}{l}\text { Inhibit protein synthesis in Gram-positive } \\
\text { bacteria }\end{array}$ \\
\hline Tetracyclines & Tetracycline & Inhibit protein synthesis; broad spectrum \\
\hline Bambermycins & Flavophospholipol & $\begin{array}{l}\text { Interferes with cell wall synthesis in } \\
\text { Gram-positive bacteria }\end{array}$ \\
\hline
\end{tabular}


piglets of 9-30\% and 6-12\% respectively have been reported (Thomke \& Elwinger, 1997). These authors also evaluated the literature for meat chickens and reported that improvements in growth rate of $3.9 \%$ and feed conversion of $2.9 \%$ could be obtained in birds on medicated feeds. Taylor (1999) indicated that carcass quality is improved when growing animals are fed growth promotants, but that effects are reduced in animals approaching slaughter weight. Improvements in milk, wool and egg production and in fertility have also been reported, but less consistently (Taylor, 1999).

It is now recognised that growth promoters also play a beneficial role in controlling some chronic diseases in intensively-reared animals. Control of such diseases not only improves productivity and economic returns, but also has implications for animal welfare.

$C$. perfringens causes necrotic enteritis in chickens and this disorder is well controlled by avoparcin, virginiamycin, zinc bacitracin, lincomycin and avilamycin (Wicker et al. 1977; Prescott et al. 1978; Hamdy et al. 1983; Jansson et al. 1992; Elwinger et al. 1995; Taylor, 1999). Prevention of subclinical necrotic enteritis improves health, welfare and production in meat chickens.

Swine dysentery, caused by Serpulina dysenteriae, and porcine proliferative enteropathy, caused by Lawsonia intracellularis, can be prevented by the use of medicated feeds. Quinoxalones are effective in controlling swine dysentery (Molnar, 1996; Commission on Antimicrobial Feed Additives, 1997), but resistance appears to emerge with tylosin, lincomycin, monensin and tiamulin (Molnar, 1996). Porcine proliferative enteropathy can be effectively prevented by tylosin or tiamulin (McOrist et al. 1996, 1997) or a range of other growth promoters including salinomycin and spiramycin (Tsinas et al. 1998). Prevention of these common conditions in pigs is a significant contributor to the improved production and well-being of pigs.

Some researchers have reported that the use of growth-promotant antibiotics reduces the shedding of salmonella (Gustafson \& Bowen, 1997); however, other researchers report no effect (Ford et al. 1981; Abou-Youssef et al. 1983), or even prolonged excretion of pathogens such as thermophilic campylobacters, Salmonella spp. and Listeria spp. (Gutzman et al. 1976; Barrow, 1989; Corpet, 1996). Kaukas et al. (1988) reported that the use of growth-promotant antibiotics in chickens selected for Enterococcus faecium at the expense of Enterococcus gallinarum.

Other benefits attributed to the use of growth promoters include environmental gains such as reduced $\mathrm{N}$ and $\mathrm{P}$ excretion and therefore less effluent production (Roth \& Kirchgessner, 1994; Verbeke \& Viaene, 1996; Gropp \& Shuhmacher, 1997). Lawrence (1997) noted that significant practical benefits accrue from use of growth promoters, including a reduction in feed, protein and water consumption as well as a reduction in slurry production and $\mathrm{N}$ and $\mathrm{P}$ excretion. Lawrence (1997) and McOrist (1997) both commented that withdrawal of growth promoters would lead to reduced profitability of farming enterprises through increased capital and operational costs.

\section{Therapeutic and prophylactic in-feed medication}

A wide range of antibiotics is used therapeutically in animals. Conventional wisdom suggests that this use does not pose a significant threat to human health, because in countries with developed animal-health systems therapeutic use is under tight regulatory control. Therapeutic use generally involves the treatment of sick animals on an individual basis, but on occasion can require the use of medicated feed or water to treat a group or pen of animals. Importantly, many countries and professional associations have developed (or are in the process of developing) 
guidelines and codes for the prudent use of antibiotics (Joint Expert Technical Advisory Committee on Antibiotic Resistance, 1999; Office International des Epizooties, 1999). These guidelines stress the need for accurate diagnosis and specific therapy for a defined period.

In some countries, restrictions apply regarding which antibiotic can be used therapeutically. For example, in Australia fluoroquinolones, amphenicols, colistin and gentamicin are not registered for use in food-producing animals. In addition, approval for use of thirdgeneration cephalosporins is severely restricted. If the recommendations of the Joint Expert Technical Advisory Committee on Antibiotic Resistance (1999) report are accepted by agricultural authorities, these restrictions will be tightened further, with the aim of minimising the use in food-producing animals of antibiotics regarded as important in human medicine.

Prophylactic use is of greater concern. Here, a wider range of antibiotics can be used and the definitions of dose rates and treatment times are subject to manipulation. Most prophylactic use involves mass medication of a group or flock of animals via feed or water. For example, in Australia tetracyclines are registered for prophylactic use for the prevention of respiratory disease in pigs. Evidence from urine-residue monitoring suggests that on occasion higher doses are used for longer periods than intended under the definition 'prophylactic use'.

Some of the antibiotics registered for prophylactic use are in categories that contain antibiotics, or are in a class that contains antibiotics of value in human medicine. Antibiotics registered for prophylactic use in Australia are tylosin, lincomycin, spectinomycin, tetracyclines, neomycin, apramycin, avoparcin, zinc bacitracin, olaquindox, dimetridazole, sulphonamides and 3-nitro-arsonic acid. This list contains most of the growth-promotant antibiotics of concern. Some medical specialists are concerned, therefore, that banning the use of growth promotants will not prevent prolonged in-feed use of such antibiotics, as they will continue to be used prophylactically (Joint Expert Technical Advisory Committee on Antibiotic Resistance, 1999).

\section{Problems associated with antibiotic use in animals}

Problems attributed to the use of antibiotics in animals include those of antibiotic residues and antibiotic resistance.

\section{Antibiotic residues}

Until very recently, controls on antibiotic use in animals focused almost exclusively on the control of residues in the tissues of treated animals. Concerns about residues revolve around allergic reactions and the possible adverse effects on the flora of the human gastrointestinal tract (selecting for resistance or transfer of resistance). Swann (1969) noted that penicillin residues in milk could provoke allergic reactions in sensitised individuals, but concluded that there were no other adverse effects associated with antibiotic residues. Triggering of allergic reactions in sensitised individuals by penicillin residues is well documented (Dewdney et al. 1991), but these authors conclude that there is no evidence that any individual has become sensitised by food residues of either penicillins or macrolides. Confirmed cases of allergy to substances in food are very rare, although adverse reactions to antibiotics have been linked to hypersensitivity (Woodward, 1991) and cases of chronic urticaria (Ormerod et al. 1987; Dayan, 1993). A rare fatal blood dyscrasia in individuals sensitised to chloramphenicol could also be triggered by chloramphenicol residues in food (Settepani, 1984).

There is little scientific information on the effect of antibiotic residues on the bacterial flora of the human intestinal tract. Clearly, such studies are very difficult to conduct (Corpet, 1993; 
Kidd, 1994), and Gorbach (1993) points out that most human studies have used therapeutic rather than residue-range concentrations and that, to date, results have been confusing. Corpet (1993) also makes the point that most resistant enterobacteria in the human gut of untreated individuals come from bacterial contamination of raw foods.

Many developed countries monitor and survey tissues from animals for antibiotic residues. Acceptable daily intakes for human subjects based on 'no-effect levels' and safety have been calculated for many antibiotics, despite the lack of accurate data. From these values, a tolerance level or maximum residue level is calculated. Established maximum residue levels are modified and often reduced as the techniques for detection of residues improve and become more sensitive. Conversely, some levels have been increased recently as data become available that facilitate better risk assessment.

\section{Antibiotic resistance in bacteria in animals}

Resistance to antibiotics associated with the use of antibiotics in animals is the issue of principal concern. First, there are concerns about transfer of antibiotic-resistant pathogens through the food chain and the risk of transfer of antibiotic-resistant genes from animal enteric flora to human pathogens. Second, there is the issue of reduced efficacy of antibiotic therapy in animals colonised with resistant bacteria. There are few comprehensive studies of antibiotic resistance in bacterial isolates from animals. However, since concerns have arisen about growth-promotant antibiotics selecting for resistance in human pathogens, more countries have set up antibiotic-resistance surveillance programmes for bacterial isolates from animals. There has been some surveillance of salmonella in the UK and Sweden since the 1970s (Commission on Antimicrobial Feed Additives, 1997; Ministry of Agriculture, Fisheries and Food, 1998) and more recently in France (Martel \& Coudert, 1993) and the USA (Fedorka-Cray et al. 1998). Denmark has established very comprehensive surveillance and reporting (Aarestrup et al. 1998a,b). The World Health Organization (1999) organised a meeting to facilitate exchange of information on progress in implementing resistance surveillance in foodborne pathogens. Programmes discussed included: the European survey of antibiotic resistance in E. faecium in animals; US national antimicrobial-resistance monitoring system for enteric bacteria; a more general European study on antibiotic resistance in bacteria of animal origin covering E. coli, salmonella, enterococci, campylobacter, staphylococci, streptococci and pasteurella; the Danish programme; the European surveillance programme for salmonella and E. coli O:157; the Canadian programme for surveillance of antimicrobial resistance in food-borne pathogens; a Japanese programme of monitoring resistance in isolates of animal origin.

One of the difficulties in comparing results from different laboratories and countries is the lack of standardisation of methods used and lack of agreed interpretive criteria. For many veterinary antibiotics, breakpoints of sensitivity and resistance have not been established and, for antibiotics also used in human medicine, medical criteria are used. For example, Riddle et al. (2000) have pointed out the errors that can occur when ciprofloxacin is used to assess resistance of veterinary isolates to fluoroquinolones used in veterinary practice.

In general, antibiotic resistance is readily detected in bacterial isolates from animals exposed to antibiotics.

\section{Antibiotic resistance in enteric bacteria}

Most concern about antibiotic resistance in animal isolates of bacteria is directed towards the enteric bacteria, E. coli, salmonella, thermophilic campylobacters and enterococci. There is 
considerable information on antibiotic resistance in E. coli and salmonella, as these bacteria are recognised pathogens in animals, but there is relatively little information about antibiotic resistance in thermophilic campylobacters and enterococci, as these bacteria are commensal enteric organisms rather than animal pathogens.

Antibiotic resistance was detected in isolates of $E$. coli from animals soon after antibiotics were incorporated into animal feeds. Studies in the UK found that, in the late 1950s, tetracycline resistance was already detectable in $E$. coli isolates from chickens and pigs fed rations containing less than $100 \mathrm{~g}$ tetracycline/t (Smith, 1967). Resistance to other antibiotics was detected as new agents were introduced for therapeutic and growth-promotant purposes (Smith, 1967; Anderson, 1968). Some workers (Linton et al. 1988; Lee et al. 1993) also noted the occurrence of tetracycline resistance in some piggeries, even though tetracyclines had not been used in those piggeries. A common finding has been that resistance persists after antibiotics are withdrawn (Smith, 1973; Rollins et al. 1976; Langlois et al. 1983; Hinton et al. 1984).

Feeding oxytetracycline to recently-weaned pigs was found to lead to a rapid increase in the incidence of tetracycline resistance, which was widely distributed among all strains of $E$. coli present, rather than being restricted to a few selected clones (Hinton et al. 1985). More recently, feeding low doses of ampicillin to chickens was shown to select for high levels of resistance to that antibiotic (El-Sam et al. 1993). Marshall et al. (1990) have described an elegant experiment that demonstrated that resistant strains of E. coli spread among animals (and to other species such as mice), even in the absence of ongoing antibiotic treatment.

In reviewing the published literature, it is clear that resistance to antibiotics has become very common in E. coli over the 50 years of use of in-feed antibiotics (Langlois et al. 1988; Aalback et al. 1991; Adesiyun \& Kaminjolo, 1992; Nijsten et al. 1993; Dunlop et al. 1998a; Matthew et al. 1998; Sunde et al. 1998; Orden et al. 1999; Lambie et al. 2000). The level of exposure affects the extent of resistance, and there are differences between antibiotics in the time taken for resistance to be evident and in the extent of the resistance that is seen. In herds and flocks treated with tetracycline, aminoglycoside and sulphonamide, widespread resistance is seen (Rollins et al. 1976; Williams Smith, 1980; Franklin, 1984; Nijsten et al. 1993; Wray et al. 1993b; Dunlop et al. 1998a; Matthew et al. 1998; Sunde et al. 1998). However, resistance to other antibiotics such as ampicillin and olaquindox is less widespread (Dunlop et al. 1998a,b; Linton et al. 1988). More recently, resistance to fluoroquinolones has been reported (Blanco et al. 1997; Heurtin-Le Corre et al. 1999). Resistance to more than one class of antibiotics is the rule rather than the exception in these published studies.

Antibiotic resistance in salmonella was also reported soon after antibiotics began to be fed at subtherapeutic levels to animals (Anderson, 1968). As salmonella is a recognised food-borne pathogen, a number of the published reports of resistance patterns in animal isolates have been linked with studies of human isolates (Threlfall et al. 1993; Seyfarth et al. 1997) or with concerns about resistance to particular antibiotics (Wray et al. 1986; Heurtin-Le Corre et al. 1999). Some countries have carried out surveys of resistance in animal isolates of salmonella or have ongoing antibiotic-resistance surveillance programmes (Wray et al. 1993a; Commission on Antimicrobial Feed Additives, 1997; Seyfarth et al. 1997; Baggesen \& Aarestrup, 1998; Fedorka-Cray et al. 1998; Davis et al. 1999; van der Wolf et al. 1999). The results are not easy to interpret because some reports do not distinguish between different serovars of Salmonella enterica and it is recognised that some serovars such as Typhimurium are much more likely to be resistant than other serovars such as Dublin and Enteritidis PT4 (Ministry of Agriculture, Fisheries and Food, 1998).

As with E. coli, as new antibiotics are used, so resistance in salmonella is detected; for example, apramycin resistance was reported in both $E$. coli and salmonella within 3 years of its 
licensing for use in the UK (Wray et al. 1986) and fluoroquinolone resistance within a few years of enrofloxacin first being used (Griggs et al. 1994; Heurtin-Le Corre et al. 1999). The overall conclusion is that resistance is generally less prevalent in salmonella, but that resistance to tetracyclines, sulphonamides and streptomycin is quite widespread. Antibiotic resistance in E. coli and salmonella poses problems in relation to effective treatment of these infections in animals.

Thermophilic campylobacters are enteric commensal bacteria in animals, so there are few reports on antibiotic resistance. Erythromycin-resistant campylobacters have often been reported in pigs (Elharrif \& Megraud, 1984; Hariharan et al. 1990; Moore et al. 1996), with Moore et al. (1996) reporting more frequent resistance in Campylobacter coli isolates. Aarestrup et al. (1997) found that tetracycline resistance was more common in human isolates than in pig or poultry isolates, and that there was more macrolide and streptomycin resistance in isolates from pigs than in human and poultry isolates. Resistance to ampicillin, spectinomycin, streptomycin, sulphonamides and nalidixic acid (but not fluoroquinolones) was detected in campylobacter isolates in Ireland (Lucey et al. 2000), whereas a study in Spain (Saenz et al. 2000) reported very high levels of ciprofloxacin resistance in pig and poultry isolates. In addition, there were high levels of resistance to erythromycin, ampicillin, gentamicin and amikacin in pig isolates and high levels of ampicillin and gentamicin resistance in poultry isolates. The difference between these two studies presumably reflects differences in antibiotic usage in the two countries. In an Australian study of 116 isolates, significant levels of resistance to erythromycin, clindamycin, ampicillin and tetracycline were found, but no resistance to fluoroquinolones (which are not registered for use in livestock in Australia; MD Barton and R Pratt, unpublished results).

Enterococci are also enteric commensal bacteria in animals. There was no interest or concern about resistance in these organisms until vancomycin-resistant E. faecium were detected in pigs and poultry being fed avoparcin (Danish Veterinary Laboratory, 1995). This finding provoked much interest and debate about the role of animal use of avoparcin in the development of VRE in man (Klare et al. 1995; Aarestrup et al. 1996; Jensen et al. 1998; Kruse et al. 1999). Bager et al. (1997) found that resistance occurred only on farms where avoparcin was used. Molecular studies of the glycopeptide-resistance element in E. faecium isolates from animals and human subjects found that the genetic elements encoding vancomycin resistance were indistinguishable. These findings presumably prompted investigations into resistance to other antibiotics of interest (or potential interest) in human medicine. Other types of antibiotic resistance reported in enterococcal isolates from animals include resistance to the macrolidelincosamide-streptogramin group (Dutta \& Devriese, 1982), to tylosin (Aarestrup \& Cartensen, 1998) and to virginiamycin (Hammerum et al. 1998). An Australian study (MD Barton and $\mathrm{R}$ Pratt, unpublished results) found widespread resistance to: macrolides (erythromycin and tylosin); clindamycin, tiamulin and virginiamycin; aminoglycosides (streptomycin, gentamicin, apramycin); spectinomycin, tetracycline and monensin. These was also moderately common resistance to bacitracin, a low prevalence of resistance to ampicillin and no resistance to vancomycin or teicoplanin. Recently it has been found, in a small study of commercial pig carcasses, that there was no increase in resistance to tylosin or avilamycin in isolates of enterococci from pigs fed those antibiotics as growth promoters (Davies \& Roberts, 1999).

Antibiotic-resistant bacteria have been found in environmental samples (Linton, 1986; Morinigo et al. 1990; Young, 1993) and wild-caught blue crabs (Callinectes sapidus; Marshall et al. 1996). Some of this contamination presumably comes from use of antibiotics in aquaculture, but Boon \& Cattanach (1999) reported that the incidence of antibiotic resistance was higher in native heterotrophic bacteria isolated from a river than in faecal bacteria from the 
same source. Kelley et al. (1998) drew attention to the risk of spread of antibiotic-resistant bacteria in poultry litter used as mulch or bedding.

\section{Transfer of resistant bacteria and resistance genes from animals to man}

The question of whether antibiotic use and antibiotic-resistant isolates of bacteria from animals have an impact on human health has been under scrutiny since the Swann (1969) report was published. Some of the issues have been reviewed recently (Witte, 1997, 1998; Barton, 1998). Some animal health, farming and pharmaceutical groups are reluctant to accept that there are links between antibiotic use and resistance in animal isolates and resistance in human pathogens (Shryock, 1999). However, scientific evidence is mounting, for at least some organisms and some antibiotics. For example, salmonella is a well-recognised food-borne pathogen, so resistant strains of salmonella, including Salmonella typhimurium DT104 do spread from animals to man via the food chain (Threlfall, 1992; Threlfall et al. 1993; Wall et al. 1995; Glynn et al. 1998) and by direct contact (Fone \& Barker, 1994). However, antibiotic treatment for human non-typhoidal salmonella enteritis is rarely required, and is probably contraindicated unless there is evidence of systemic infection.

Apramycin resistance in human strains of salmonella and E. coli provides evidence of transfer of resistant organisms or resistance genes from animal to human isolates, as apramycin is not used in human medicine (Wray et al. 1986; Hunter et al. 1993). A similar situation has been reported, with spread of resistance to nourseothricin, an antibiotic growth promoter of a class of antibiotic not used in human medicine. Plasmid-borne resistance was detected not only in E. coli from treated pigs, pig farm employees and their families, but also in that from residents of nearby villages and towns (Hummel et al. 1986).

Campylobacter is another food-borne pathogen. Fluoroquinolone-resistant strains of Campylobacter jejuni were isolated from human subjects soon after enrofloxacin started to be used in poultry in Europe (Jacobs-Reitsma et al. 1994; Velazquez et al. 1995). A study in the USA documents not only a temporal association between use of fluoroquinolones to treat chickens and resistance in human isolates but also that molecular sub-typing indicated that resistant strains from chickens were very similar to resistant strains from human subjects (Smith et al. 1998). A further concern with fluoroquinolone resistance is resistance in animal isolates of salmonella (Griggs et al. 1994) or transfer of this resistance from campylobacter (Herikstad et al. 1997) or E. coli to multiresistant salmonella (Heurtin-Le Corre et al. 1999).

There is observational evidence from case studies indicating direct spread of resistant commensal enteric bacteria from animals to man (Levy et al. 1976; Hunter et al. 1994; Nijsten et al. 1994, 1996; van den Bogaard et al. 1997; Wegener et al. 1997; Stobberringh et al. 1999; Fey et al. 2000). Although it has been easy to find resistant bacteria in animals and similar resistance patterns in isolates from human subjects, until recently few isolations have been made from food (Klein et al. 1998; Manie et al. 1998; Quednau et al. 1998; Duffy et al. 1999).

The early evidence for transfer of glycopeptide resistance from animals to man came from observational studies (e.g. Danish Veterinary Laboratory, 1995; Aarestrup et al. 1996), but scientific evidence based on molecular analysis of the distribution of the vanA resistance determinant Tn1546 is now compelling (Jensen et al. 1998; Simonsen et al. 1998; van den Braak et al. 1998; Descheemaeker et al. 1999; Wegener et al 1999). Molecular studies have helped clarify the link between avoparcin-resistant enterococci and vanA VRE in man. Although there is considerable genomic heterogeneity in vanA-positive VRE from human and animal isolates, indistinguishable patterns are found across pig, poultry and human isolates. 
Resistance mediated by van B has not been confirmed in non-human enterococci (Woodford, 1998). Resistance mediated by van A is the commonest form of vancomycin resistance in human isolates in Europe, whereas van B resistance is more commonly seen in the USA (where avoparcin is not used in animal feeds) and Australia.

Currently, there is much debate about resistance in enterococci to some new human antibiotic products. Virginiamycin, a streptogramin antibiotic, has been used for many years as a growth-promotant antibiotic without any concerns, as there were no related human products. As problems with MRSA and VRE grew, a related streptogramin quinupristin-dalfopristin was developed (Bryson \& Spencer, 1996; Rubenstein \& Bompart, 1997) with specific activity against multiresistant Gram-positive bacteria. However, concerns were soon raised about whether the use of virginiamycin had selected for resistant enterococci, and whether there would be cross-resistance with quinupristin-dalfopristin. A report (Danish Veterinary Laboratory, 1998) indicated that the use of virginiamycin did select for resistant E. faecium, and Hammerum et al. (1998) and Jensen et al. (1998) detected the satA and $v g b$ genes, which encode streptogramin resistance, in virginiamycin-resistant E. faecium isolates from animals and man. Quinupristin-dalfopristin resistance was detected in a high proportion of a small number of strains of virginiamycin-resistant E. faecium, including isolates collected before any quinupristin-dalfopristin had been used but where virginiamycin had been used as a growth promoter for many years (Werner et al. 1998). In addition, a recent European study of more than 4000 enterococci reported that $75 \%$ of Enterobacter faecalis isolates and $15 \%$ of other enterococci were resistant to quinupristin-dalfopristin (Schouten et al. 1999).

Another promising human antibiotic for treating multiresistant Gram-positive infections is everninomicin ( $\mathrm{SCH}$ 27899). This antibiotic is an orthosomycin, as is avilamycin, which has been used as a growth promoter for some years (when it was introduced there were no related clinical products). Avilamycin-resistant E. faecium and E. faecalis have been found to have reduced susceptibility to everninomicin (Aarestrup, 1998). However, in the European study mentioned earlier (Schouten et al. 1999), all enterococci (mostly E. faecalis in this study) were sensitive to everninomicin.

\section{Conclusions}

Antibiotic-resistant human pathogens are a major challenge in human medicine (Collignon, 1997; Turnidge, 1998; Williams \& Heymann, 1998; Guillemot, 1999). There is some risk that excessive attention to transfer of antibiotic-resistant bacteria or genes from animals to man will divert attention from the need to address problems inherent in the medical use of antibiotics. Antibiotic-resistance problems in human medicine include those of MRSA, VRE, multiresistant Mycobacterium tuberculosis, penicillin-resistant pneumococci, multiresistant Gram-negative organisms and extended-spectrum $\beta$-lactamase-producing Gram-negative bacteria (Gold \& Moellering, 1996; Collignon, 1997). For most of these organisms there is no connection with antibiotic use in animals, but there are exceptions.

An important issue is MRSA, and it was the need in many countries to find an effective treatment for this organism that led to a rapid increase in vancomycin use, particularly in the USA. Kirst et al. (1998) reported that vancomycin use in the USA increased from $2000 \mathrm{~kg}$ in 1984 to over $11000 \mathrm{~kg}$ in 1996 , whereas in The Netherlands medical use increased from 9 to $60 \mathrm{~kg}$ over the same period. VRE started to emerge as a problem in the late 1980s, particularly in the USA. Vancomycin is frequently the drug of last resort in treatment of MRSA. It is worth noting that, although strains of MRSA with reduced susceptibility to vancomycin have emerged 
(Anonymous, 1997; Lessing \& Raftery, 1998; Woodford et al. 2000), the mechanism of resistance is unrelated to that seen in VRE. A high proportion of the VRE problems in the USA is caused by van $\mathrm{B}$ VRE, which presumably emerged because of the high selection pressure in American hospitals. As avoparcin is not registered for use in the USA, it is more difficult to account for vanA VRE there. A survey in the USA failed to isolate VRE from healthy volunteers with no hospital exposure, or from chickens and chicken-farm effluent ponds (Coque et al. 1996). However, it is now clear from molecular epidemiological studies that animals carrying vanA VRE in their intestinal tracts are a source of these organisms for human subjects in countries where avoparcin is (or has been) used as a growth promoter.

Human enteric infections with campylobacter and salmonella are rarely treated with antibiotics; antibiotic resistance is, therefore, less important than it is with some of the other more serious infections. However, it is still not acceptable for individuals to be unnecessarily exposed to resistant strains of bacteria in their food. It is clear that antibiotic resistance is an issue with animal strains of campylobacter, salmonella and E. coli, and that these organisms infect individuals as a result of contamination of animal carcasses and meat. One control strategy is to reduce carcass contamination with these enteric bacteria from animals through improvements in on-farm management, transport, abattoir lairage management and killing-floor and chiller practices and controls. However, antibiotic resistance itself must also be controlled.

Farmers as the end-users of antibiotics must be made more aware of the antibiotic-resistance problem, and it is crucial that on-farm Quality Assurance programmes address the responsible use of antibiotics more broadly than by merely trying to reduce the incidence of residues in tissues. Clearly, there is a case for reducing antibiotic usage on farms. Some of this reduction can come from development of, and adherence to, guidelines for the prudent use of antibiotics. It is also essential to strengthen the segregation of antibiotics into those for human use and those approved for animal use. It is difficult to justify the use of potentially-valuable antibiotics as growth-promotant agents, and long-term use of antibiotics for prevention of disease clearly contributes to the antibiotic-resistance problem. Alternatives to antibiotics for disease prevention should be further studied and, if beneficial, implemented. Examples currently under investigation include improvements in housing, management systems and feed formulation, and the development of more vaccines, probiotics and competitive exclusion products. It is important to assess these approaches to ensure, for example, that probiotics and competitive exclusion products do not themselves carry antibiotic-resistance genes. However, it will always be necessary to have available a range of antibiotics for therapeutic use in animals.

It is worth considering that, in many ways, the damage has been done with the currentlyavailable antibiotics, as resistance is already well established in bacterial populations in man, animals and the environment. Salyers \& Amábile-Cuevas (1997) point out that, although withdrawal of an antibiotic can lead to a decline in resistance to that antibiotic, resistance levels rapidly rebound if the antibiotic is reintroduced. Bager et al. (1999) found that there was a statistically significant decline in glycopeptide resistance in E. faecium isolates from pigs and poultry over the 3 years following the withdrawal of avoparcin from use in Denmark. However, resistance to others, particularly tetracyclines, persists for a long time, even in the absence of exposure to the antibiotic (Smith, 1973; Rollins et al. 1976; Langlois et al. 1983; Hinton et al. 1984).

Be that as it may, it is essential to protect the value of antibiotics that have not yet been compromised. For example, countries such as Australia that have not licensed fluoroquinolones for use in food-producing animals and have restricted the use of third-generation cephalosporins should maintain that stance. All new antibiotics or new antibiotic uses in animals should be assessed before licensing for their potential to cause harm to human health, including 
the capacity to cause resistance in human pathogens and to select for cross-resistance with important human antibiotics.

Consumers are concerned about the wholesomeness and safety of foods. Increasing litigation based on the premise that individuals should not suffer any harm from food must alert the farming industries to the need to ensure that animal products are safe and healthy for consumers. The aim should be to produce a product with no residues and with minimum levels of bacteria that have no acquired antibiotic resistance. Controls on animal usage will not resolve the current problems in human medicine, but may well help to extend the useful life of any new classes of antibiotics, if and when they are introduced.

\section{References}

Aalback B, Rasmussen J, Nielsen B \& Olsen JE (1991) Prevalence of antibiotic-resistant Escherichia coli in Danish pigs and cattle. APMIS 99, $1103-1110$.

Aarestrup FM (1998) Association between decreased susceptibility to a new antibiotic for treatment of human diseases, everninomicin (SCH 27899) and resistance to an antibiotic used for growth promotion in animals, avilamycin. Microbial Drug Resistance 4, 137-141.

Aarestrup FM, Ahrens P, Madsen M, Pallesen LV, Poulsen L \& Westh H (1996) Glycopeptide susceptibility among Danish Enterococcus faecium and Enterococcus faecalis isolates of animal and human origin and PCR identification of genes within the VanA cluster. Antimicrobial Agents and Chemotherapy 40, 1938-1940.

Aarestrup FM, Bager F, Jensen JE, Madsen M, Meyling A \& Wegener HC (1998a) Surveillance of antimicrobial resistance in bacteria isolated from food animals to antimicrobial growth promoters and related therapeutic agents in Denmark. APMIS 106, 606-622.

Aarestrup FM, Bager F, Jensen JE, Madsen M, Meyling A \& Wegener HC (1998b) Resistance to antimicrobial agents used for animal therapy in pathogenic, zoonotic and indicator bacteria isolated from different food animals in Denmark: a baseline study for the Danish Integrated Antimicrobial Resistance Monitoring Programme (DANMAP). APMIS 106, 745-770.

Aarestrup FM \& Cartensen B (1998) Effect of tylosin used as a growth promoter on the occurrence of macrolideresistant enterococci and staphylococci in pigs. Microbial Drug Resistance 4, 307-312.

Aarestrup FM, Nielsen EM, Madsen M \& Engberg J (1997) Antimicrobial susceptibility patterns of thermophilic Campylobacter spp. from humans, pigs, cattle and broilers in Denmark. Antimicrobial Agents and Chemotherapy 41, 2244-2250.

Abou-Youssef MH, Di Cuollo CJ, Free SM \& Scott GC (1983) The influence of a feed additive level of virginiamycin on the course of an experimentally induced Salmonella typhimurium infection in broilers. Poultry Science 62, 3037.

Adesiyun AA \& Kaminjolo JS (1992) Susceptibility to antibiotic of Escherichia coli strains isolated from diarrhoeic and non-diarrhoeic livestock on Trinidad. Revue d'Elevage et de Médecine Vétérinaire des Pays Tropicaux 45, 260262.

Anderson ES (1968) Drug resistance in Salmonella typhimurium and its implications. British Medical Journal 3, 333 339.

Anonymous (1997) Reduced susceptibility of Staphylococcus aureus to vancomycin-Japan, 1996. Morbidity and Mortality Weekly Report 46, 624-626.

Bager F, Aarestrup FM, Madsen M \& Wegener HC (1999) Glycopeptide resistance in Enterococcus faecium from broilers and pigs following discontinued use of avoparcin. Microbial Drug Resistance 5, 53-56.

Bager F, Madsen M, Christensen J \& Aarestrup FM (1997) Avoparcin used as a growth promoter is associated with the occurrence of vancomycin-resistant Enterococcus faecium on Danish poultry and pig farms. Preventive Veterinary Medicine 31, 95-112.

Baggesen DL \& Aarestrup FM (1998) Characterisation of recently emerged multiple antibiotic-resistant Salmonella enterica serovar typhimurium DT104 and other multiresistant phage types from Danish pig herds. Veterinary Record 143, 95-97.

Barrow PA (1989) Further observations on the effect of feeding diets containing avoparcin on the excretion of salmonellas by experimentally infected chickens. Epidemiology and Infection 102, 239-252.

Barton MD (1998) Does the use of antibiotics in animals affect human health? Australian Veterinary Journal 76, $177-$ 179.

Blanco JE, Blanco M, Mora A \& Blanco J (1997) Prevalence of bacterial resistance to quinolones and other antimicrobials among avian Escherichia coli strain isolates from septicaemic and healthy chickens in Spain. Journal of Clinical Microbiology 35, 2184-2185. 
Boon PI \& Cattanach M (1999) Antibiotic resistance of native and faecal bacteria isolated from rivers, reservoirs and sewage treatment facilities in Victoria, south-eastern Australia. Letters in Applied Microbiology 28, 164-168.

Bryson HM \& Spencer CM (1996) Quinupristin/dalfopristin. Drugs 52, 406-415.

Collignon PJ (1997) Antibiotic resistance: is it leading to the re-emergence of many infections from the past? In Recent Advances in Microbiology vol. 5, pp. 203-256 [V. Asche, editor]. Melbourne, Victoria: The Australian Society for Microbiology Inc.

Commission on Antimicrobial Feed Additives (1997) Antimicrobial Feed Additives. Stockholm: Ministry of Agriculture.

Congress of the United States (1995) Impacts of Antibiotic Resistant Bacteria. Washington, DC: Government Printing Office.

Coque TM, Tomayko JF, Ricke SC, Okhyusen PC \& Murray BE (1996) Vancomycin-resistant enterococci from nosocomial community and animal sources in the United States. Antimicrobial Agents and Chemotherapy 40, 26052609.

Corpet DE (1993) An evaluation of methods to assess the effect of antimicrobial residues on the human gut flora. Veterinary Microbiology 35, 199-212.

Corpet DE (1996) Microbiological hazards for humans of antimicrobial growth promoter use in animal production. Revue de Médecine Vétérinaire 147, 851-862.

Danish Veterinary Laboratory (1995) The Effect of Avoparcin Used as a Feed Additive on the Occurrence of Vancomycin Resistant Enterococcus faecium in Pig and Poultry Production. Copenhagen, Denmark: Danish Veterinary Laboratory.

Danish Veterinary Laboratory (1998) The Effect of Virginiamycin on Bacterial Antimicrobial Resistance Development. Copenhagen, Denmark: Danish Veterinary Laboratory.

Davies R \& Roberts TA (1999) Antimicrobial susceptibility of enterococci recovered from commercial swine carcasses: effect of feed additives. Letters in Applied Microbiology 29, 327-333.

Davis MA, Hancock DD, Besser TE, Rice DH, Gay JM, Gay C, Gearhart L \& DiGiacomo R (1999) Changes in antimicrobial resistance among Salmonella enterica Serovar typhimurium isolates from humans and cattle in the Northwestern United States, 1982-1997. Emerging Infectious Diseases 5, 802-806.

Dayan AD (1993) Allergy to antimicrobial residues in food: assessment of the risk to man. Veterinary Microbiology 35, 213-226.

Descheemaeker PR, Chapelle S, Devriese LA, Butaye P, Vandamme P \& Goossens H (1999) Comparison of glycopeptide-resistant Enterococcus faecium isolates and glycopeptide resistance genes of human and animal origin. Antimicrobial Agents and Chemotherapy 43, 2032-2037.

Dewdney JM, Maes L, Raynaud JP, Blanc F, Scheid JP, Jackson T, Lens S \& Verschueren C (1991) Risk assessment of antibiotic residues of beta-lactams and macrolides in food products with regard to their immuno-allergic potential. Food Chemistry and Toxicology 29, 477-483.

Duffy G, Cloak OM, O’Sullivan MG, Guillet A, Sheridan JJ, Blair IS \& McDowell DA (1999) The incidences and antibiotic resistance profiles of Salmonella spp. on Irish retail meat products. Food Microbiology 16, 623-631.

Dunlop H, McEwan S, Meek AH, Black WD, Friendship RM \& Clarke RC (1998a) Prevalences of resistance to seven antimicrobials among faecal flora of swine on 34 farrow-finish farms in Ontario. Preventive Veterinary Medicine 34, $265-282$

Dunlop H, McEwan SA, Meek AH, Clarke RC, Black WD \& Friendship RM (1998b) Associations among antimicrobial drug treatments and antimicrobial resistance of fecal Escherichia coli of swine on 34 farrow-to-finish farms in Ontario, Canada. Preventive Veterinary Medicine 34, 283-305.

Dutta GN \& Devriese L (1982) Resistance to macrolide-lincosamide-streptogramin antibiotics in enterococci from the intestines of animals. Research in Veterinary Science 33, 70-72.

Elharrif Z \& Megraud F (1984) Sensitivity of Campylobacter jejuni/coli to 11 antibiotics. Pathologie Biologie 32, 536539.

El-Sam S, Linton AH, Bennett PM \& Hinton M (1993) Effects of low concentrations of ampicillin on the intestinal Escherichia coli of chickens. Journal of Applied Bacteriology 75, 108-112.

Elwinger K, Engström B, Berndtson E, Fossum O \& Waldenstedt L (1995) Effect of Maxus (avilamycin), Avotan (avoparcin), Monteban (narasin) and Elanco-ban (monensin-Na) on the Caecal Growth of Clostridium perfringens in Broilers. Report. Uppsala: Swedish University of Agricultural Sciences.

European Federation of Animal Health (1998) The microbial threat. Animal Pharm issue no. 405, 1-4.

Fedorka-Cray PJ, Miller M, Tollefson L, Dargatz DA \& Wineland NE (1998) National Antimicrobial Susceptibility Monitoring Program-Veterinary Isolates, April 1998. Athens, GA: USDA-ARS-RRC.

Feinman SE (1998) Antibiotics in animal feed-drug resistance revisited. American Society for Microbiology News 64, 24-30.

Fey PD, Safranek TJ, Rupp ME, Dunne EF, Ribot E, Iwen PC, Bradfors PA, Angulo FJ \& Hinrichs SH (2000) Ceftriaxone-resistant salmonella infection acquired by a child from cattle. New England Journal of Medicine 342, 1242-1249.

Fone DL \& Barker RM (1994) Associations between human and farm animal infections with Salmonella typhimurium DT104 in Herefordshire. CDR Review 4, R136-R140. Available at http://www.phls.co.uk/publications/cdr.htm

Ford AM, Fagerberg DJ, Quarles CL, George BA \& McKinley GA (1981) Influence of salinomycin on incidence, shedding and antimicrobial resistance of Salmonella typhimurium in experimentally infected broiler chicks. Poultry Science 60, 2441-2453. 
Franklin A (1984) Antimicrobial drug resistance in porcine enterotoxigenic Escherichia coli of O-group 149 and nonenterotoxigenic Escherichia coli. Veterinary Microbiology 9, 467-475.

General Accounting Office (1999) Food Safety: The Agricultural Use of Antibiotics and Its Implications for Human Health. Report. Washington DC: General Accounting Office.

Glynn KM, Bopp C, Dewitt W, Dabney P, Mokhtar M \& Angulo F (1998) Emergence of multidrug-resistant Salmonella enterica serotype Typhimurium DT104 infections in the United States. New England Journal of Medicine 338, $1333-1338$.

Gold HS \& Moellering RC (1996) Antimicrobial-drug resistance. New England Journal of Medicine 335, 1445-1453.

Gorbach SL (1993) Perturbation of intestinal microflora. Veterinary and Human Toxicology 35, Suppl. 1, 15-23.

Griggs DJ, Hall MC, Jin YF \& Piddock LJV (1994) Quinolone resistance in veterinary isolates of salmonella. Journal of Antimicrobial Chemotherapy 33, 1173-1189.

Gropp JM \& Shuhmacher A (1997) Antimicrobial growth promoters in animal husbandry. In The Medical Impact of the Use of Antimicrobials in Food Animals, section 2.1.1b. Geneva: WHO.

Guillemot D (1999) Antibiotic use in humans and bacterial resistance. Current Opinion in Microbiology 2, 494-498.

Gustafson RH \& Bowen RE (1997) Antibiotic use in animal agriculture. Journal of Applied Bacteriology 83, 531 -541.

Gutzman F, Layton H, Simkins K \& Jarolmen H (1976) Influence of antibiotic-supplemented feed on occurrence and persistence of Salmonella typhimurium in experimentally infected swine. American Journal of Veterinary Research 37, 649-655.

Hamdy AH, Thomas RW, Yancey RJ \& Davis RB (1983) Therapeutic effect of optimal lincomycin concentration in drinking water on necrotic enteritis in broilers. Poultry Science, 62, 589-591.

Hammerum A, Jensen LB \& Aarestrup FM (1998) Detection of the satA gene and transferability of virginiamycin resistance in Enterococcus faecium from farm animals. FEMS Microbiology Letters 168, 145-151.

Hariharan H, Wright T \& Long J (1990) Isolation and antimicrobial susceptibility of Campylobacter coli and Campylobacter jejuni from slaughter hogs. Microbiologica 13, 1-6.

Health Council of The Netherlands (1998) Antimicrobial Growth Promoters. Committee on Antimicrobial Growth Promoters, Report. The Hague, The Netherlands: Health Council of The Netherlands.

Heidelberg Appeal Nederland Foundation (1998) Emergence of a Debate: AGPs and Public Health. Report. [A Bezoen, W van Haren and JC Hanekamp, editors]. Amsterdam, The Netherlands: Heidelberg Appeal Nederland Foundation.

Herikstad H, Hayes P, Mokhtar M, Fracaro ML, Threlfall EJ \& Angulo FJ (1997) Emerging quinolone-resistant Salmonella in the United States. Emerging Infectious Diseases 3, 371-372.

Heurtin-Le Corre C, Donnio PY, Perrin M, Travert MF \& Avril JL (1999) Increasing incidence and comparison of nalidixic acid-resistant Salmonella enterica subsp enterica serotype typhimurium isolates from humans and animals. Journal of Clinical Microbiology 37, 266-269.

Hinton M, Hampson DJ \& Linton AH (1985) The effects of oxytetracycline on the intestinal Escherichia coli flora of newly weaned pigs. Journal of Hygiene (London) 95, 77-85.

Hinton M, Rixson PD, Allen V \& Linton AH (1984) The persistence of drug resistant Escherichia coli strains in the majority faecal flora of calves. Journal of Hygiene (Cambridge) 93, 547-557.

House of Lords (1998) Resistance to Antibiotics and Other Antimicrobial Agents. Select Committee on Science and Technology, Seventh Report (Session 1997-98). London: The Stationery Office, Available at http://www. parliament.the-stationery-office.co.uk/pa/1d199798/1dselect/ldscte.../st0701ht

Hummel R, Tschape H \& Witte W (1986) Spread of plasmid-mediated nourseothricin resistance due to antibiotic use in animal husbandry. Journal of Basic Microbiology 26, 461-466.

Hunter JE, Bennett M, Hart CA, Shelley JC \& Walton JR (1994) Apramycin-resistant Escherichia coli isolated from pigs and a stockman. Epidemiology and Infection 112, 473-480.

Hunter JE, Hart CA, Shelley JC, Walton JR \& Bennett M (1993) Human isolates of apramycin-resistant Escherichia coli which contain the genes for the AAC(3)IV enzyme. Epidemiology and Infection 110, 253-259.

Jacobs-Reitsma WF, Kan CA \& Bolder NM (1994) The induction of quinolone resistant Campylobacter bacteria in broilers by quinolone treatment. Letters in Applied Microbiology 19, 228-231.

Jansson L, Elwinger K, Engström B, Fossum O \& Teglöf B (1992) Clinical Test of the Efficacy of Virginiamycin and Dietary Enzyme Supplementation Against Necrotic Enteritis (NE) Infection in Broilers. Publication 638. Uppsala, Sweden: Swedish University of Agricultural Sciences.

Jensen LB, Ahrens P, Dons L, Jones RN, Hammerum AM \& Aarestrup FM (1998) Molecular analysis of Tn1546 in Enterococcus faecium isolated from animals and humans. Journal of Clinical Microbiology 36, 437-442.

Jin S (1997) Regulation, realities and recommendation on antimicrobial use in food animal production in China. In The Medical Impact of the Use of Antimicrobials in Food Animals, section 2.3.4. Geneva: WHO.

Joint Expert Technical Advisory Committee on Antibiotic Resistance (1999) The Use of Antibiotics in Food-producing Animals: Antibiotic-resistant Bacteria in Animals and Humans. Canberra: Commonwealth of Australia.

Kaukas A, Hinton M \& Linton AH (1988) The effect of growth-promoting antibiotics on the faecal enterococci of healthy young chickens. Journal of Applied Bacteriology 64, 57-64.

Kelley TR, Pancorbo OC, Merka WC \& Barnhart HM (1998) Antibiotic resistance of litter isolates. Poultry Science 77, 243-247.

Kidd RM (1994) The Potential Risk of Effects of Antimicrobial Residues on Human Gastro-intestinal Flora. Report. Brussels, Belgium: Fédération Européenne de la Santé Animale. 
Kirst HA, Thompson DG \& Nicas TI (1998) Historical usage of vancomycin. Antimicrobial Agents and Chemotherapy 42, $1303-1304$.

Klare I, Heier H, Claus H, Reissbrodt R \& Witte W (1995) vanA-mediated high-level glycopeptide resistance in Enterococcus faecium from animal husbandry. FEMS Microbiology Letters 125, 165-171.

Klein G, Pack A \& Reuter G (1998) Antibiotic resistance patterns of enterococci and occurrence of vancomycinresistant enterococci in raw minced beef and pork in Germany. Applied and Environmental Microbiology 64, 18251830.

Kruse H, Johansen BK, Rorovik LM \& Schiller G (1999) The use of avoparcin as a growth promoter and the occurrence of vancomycin-resistant Enterococcus species in Norwegian poultry and swine production. Microbial Drug Resistance 5, 135-139.

Lambie N, Ngeleka M, Brown G \& Ryan J (2000) Retrospective study on Escherichia coli infections in broilers subjected to postmortem examination and antibiotic resistance of isolates in Trinidad. Avian Diseases 44, $155-160$.

Langlois BE, Cromwell GL, Stahly TS, Dawson KA \& Hays VW (1983) Antibiotic resistance of coliforms after longterm withdrawal of therapeutic and subtherapeutic antibiotic use in a swine herd. Applied and Environmental Microbiology 45, 1433-1434.

Langlois BE, Dawson KA, Leak I \& Aaron DK (1988) Effect of age and housing location on antibiotic resistance of fecal coliforms from pigs in a non-antibiotic exposed herd. Applied and Environmental Microbiology 54, 13411344.

Lawrence K (1997) Growth promoters. In The Medical Impact of the Use of Antimicrobials in Food Animals. EDG general comments. Geneva: WHO.

Lee C, Langlois BE \& Dawson KA (1993) Detection of tetracyline resistance determinants in pig isolates from three herd with different histories of antimicrobial agent exposure. Applied and Environmental Microbiology 59, 14671472.

Lessing MPA \& Raftery MJ (1998) Vancomycin-resistant Staphylococcus aureus. Lancet 351, 601-602.

Levy SB, FitzGerald GB \& Macone AB (1976) Changes in the intestinal flora of farm personnel after introduction of a tetracycline-supplemented feed on a farm. New England Journal of Medicine 295, 583-588.

Linton AH (1986) Flow of resistance genes in the environment and from animals to man. Journal of Antimicrobial Chemotherapy 18, Suppl. C, 189-197.

Linton AH, Hedges AJ \& Bennett PM (1988) Monitoring for the development of antimicrobial resistance during the use of olaquindox as feed additive on commercial pig farms. Journal of Applied Bacteriology 64, 311-327.

Lucey B, Crowley D, Moloney P, Cryan B, Daly M, O'Halloran F, Threlfall EJ \& Fanning S (2000) Integron-like structures in Campylobacter spp. of human and animal origin. Emerging Infectious Diseases 6, 50-55.

McOrist S (1997) Use of antimicrobials in food production-scope, policies and practices. In The Medical Impact of the Use of Antimicrobials in Food Animals, section 2.1.1. Geneva: WHO.

McOrist S, Morgan J, Veenhuizen MF, Lawrence K \& Kroger HW (1997) Oral administration of tylosin phosphate for treatment and prevention of proliferative enteropathy in pigs. American Journal of Veterinary Research 58, 136139.

McOrist S, Smith SH, Shearn MF, Carr MM \& Miller DJ (1996) Treatment and prevention of porcine proliferative enteropathy with oral tiamulin. Veterinary Record 139, 615-618.

Manie T, Khan S, Brozel VS, Veith WJ \& Gouws PA (1998) Antimicrobial resistance of bacteria isolated from slaughtered and retail chickens in South Africa. Letters in Applied Microbiology 26, 253-258.

Marshall B, Petrowski D \& Levy S (1990) Inter- and intra-species spread of Escherichia coli in a farm environment in the absence of antibiotic usage. Proceedings of the National Academy of Sciences USA 87, 6609-6613.

Marshall DL, Kim JJ \& Donnelly SP (1996) Antimicrobial susceptibility and plasmid-mediated streptomycin resistance of Plesiomonas shigelloides isolated from blue crab. Journal of Applied Bacteriology 81, 195-200.

Martel J \& Coudert M (1993) Bacterial resistance monitoring in animals: the French national experiences of surveillance schemes. Veterinary Microbiology 35, 321-338.

Matthew AG, Upchurch W \& Chattin SE (1998) Incidence of antibiotic resistance of fecal Escherichia coli isolated from commercial swine farms. Journal of Animal Science 76, 429-434.

Ministry of Agriculture, Fisheries and Food (1998) A Review of Antimicrobial Resistance in the Food Chain. Report. London: MAFF.

Molnar L (1996) Sensitivity of strains of Serpulina hyodysenteriae isolated in Hungary to chemotherapeutic drugs. Veterinary Record 138, 158-160.

Moore J, Madden H, Kerr JR, Wilson TS \& Murphy PG (1996) Erythromycin resistant thermophilic Campylobacter species isolated from pigs. Veterinary Record 138, 306-307.

Morinigo MA, Cornax R, Castro D, Jiminez-Notaro M, Romero P \& Borrego JJ (1990) Antibiotic resistance of salmonella strains isolated from natural polluted waters. Journal of Applied Bacteriology 68, 297-302.

National Research Council, Institute of Medicine (1998) The Use of Drugs in Food Animals: Benefits and Risks. Committee on Drug Use in Food Animals, Report. Washington DC: National Academy Press.

Nijsten R, London N, van den Bogaard A \& Stobberingh E (1993) Antibiotic resistance of Enterobacteriaceae isolated from the faecal flora of fattening pigs. Veterinary Quarterly 15, 152-157.

Nijsten R, London N, van den Bogaard A \& Stobberingh E (1994) Resistance in faecal Escherichia coli isolated from pig farmers and abattoir workers. Epidemiology and Infection 113, 45-52. 
Nijsten R, London N, van den Bogaard A \& Stobberingh E (1996) Antibiotic resistance among Escherichia coli isolated from faecal samples of pig farmers and pigs. Journal of Antimicrobial Chemotherapy 37, 1131-1140.

Office International des Epizooties (1999) The Use of Antibiotics in Animals - Ensuring the Protection of Public Health. Proceedings of the European Scientific Conference, 24-26 March 1999. Paris, France: OIE.

Orden JA, Ruiz-Santa-Quiteria JA, Garcia S, Cid D \& de la Fuente R (1999) In-vitro activities of cephalosporins and quinolones against Escherichia coli strains isolated from diarrheic dairy calves. Antimicrobial Agents and Chemotherapy 43, 510-513.

Ormerod AD, Reid TM \& Main RA (1987) Penicillin in milk - its importance in urticaria. Clinical Allergy 17, $229-234$.

Panin AN, Violin BV \& Kovalev VF (1997) Some problems due to antibiotic resistance and application of feed antibiotics in Russia. In The Medical Impact of the Use of Antimicrobials in Food Animals, section 2.3.9. Geneva: WHO.

Prescott JF (1997) Antibiotics: Miracle drugs or pig food? Canadian Veterinary Journal 38, 763-766.

Prescott JF \& Baggot JD (1993) Antimicrobial Therapy in Veterinary Medicine, 2nd ed, pp. 564-565. Ames, IA: Iowa State University Press.

Prescott JF, Sivendra R \& Barnum DA (1978) The use of bacitracin in the prevention and treatment of experimentallyinduced necrotic enteritis in the chicken. Canadian Veterinary Journal 19, 181-183.

Quednau M, Ahrne S, Petersson AC \& Molin G (1998) Antibiotic-resistant strains of Enterococcus isolated from Swedish and Danish retailed chicken and pork. Journal of Applied Microbiology 84, 1163-1170.

Riddle C, Lemons CL, Papich M \& Altier C (2000) Evaluation of ciprofloxacin as a representative of veterinary fluoroquinolones in susceptibility testing. Journal of Clinical Microbiology 38, 1636-1637.

Rollins LD, Gaines SA, Porcurull DW, Mercer HD \& Frobish LT (1976) Persistence of transferable drug resistance in the lactose-fermenting enteric flora of swine following antimicrobial feeding. Canadian Journal of Comparative Medicine 40, 175-183.

Roth FX \& Kirchgessner M (1994) The influence of avilamycin and tylosin on faecal excretion of nitrogen and amino acids in growing pigs. Agrobiology Research 47, 147-155.

Rubenstein E \& Bompart F (1997) Activity of quinupristin/dalfopristin against gram-positive bacteria: clinical application and therapeutic potential. Journal of Antimicrobial Chemotherapy 39, Suppl. A, 139-143.

Rutter JM (1997) Use of anti-infective drugs in the UK - types of use and conditions/legislation for applications. In The Medical Impact of the Use of Antimicrobials in Food Animals, section 2.3.5. Geneva: WHO.

Saenz Y, Zarazaga M, Lantero M, Gastanares MJ, Bacquero F \& Torres C (2000) Antibiotic resistance in campylobacter strains isolated from animals, foods and human in Spain in 1997-1998. Antimicrobial Agents and Chemotherapy 44, 267-271.

Salyers AA \& Amábile-Cuevas CF (1997) Why are antibiotic resistance genes so resistant to elimination? Antimicrobial Agents and Chemotherapy 41, 2321-2325.

Schouten MA, Voss A \& Hoogkamp-Korstanje JA (1999) Antimicrobial susceptibility patterns of enterococci causing infections in Europe. The European VRE Study Group. Antimicrobial Agents and Chemotherapy 43, 2542-2546.

Scientific Committee for Animal Nutrition (1996) Report of the Scientific Committee for Animal Nutrition (SCAN) on the Possible Risks for Humans in the Use of Avoparcin as a Feed Additive. Brussels, Belgium: European Commission.

Scientific Committee for Animal Nutrition (1998a) Report of the Scientific Committee for Animal Nutrition (SCAN) on Efficacy and Risk for Users of the Therapeutic Macrolide Antibiotics Tylosin and Spiramycin Used as Feed Additives. Brussels, Belgium: European Commission.

Scientific Committee for Animal Nutrition (1998b) Report of the Scientific Committee for Animal Nutrition (SCAN) on the Immediate and Longer-term Risk to the Value of Streptogramins in Human Medicine Posed by the Use of Virginiamycin as an Animal Growth Promoter. Brussels, Belgium: European Commission.

Settepani JA (1984) The hazard of using chloramphenicol in food animals. Journal of the American Veterinary Medical Association 184, 30-39.

Seyfarth AM, Wegener HC \& Frimodt-Moller N (1997) Antimicrobial resistance in Salmonella enterica subsp. enterica serovar typhimurium from humans and production animals. Journal of Antimicrobial Chemotherapy 40, 67-75.

Shryock TR (1999) Relationship between usage of antibiotics in food-producing animals and the appearance of antibiotic resistant bacteria. International Journal of Antimicrobial Agents 12, 275-278.

Simonsen GS, Haaheim H, Dahl KH, Kruse H, Lovseth A, Olsvik O \& Sundsfjord A (1998) Transmission of Van-A type vancomycin-resistant enterococci and van A resistance elements between chicken and humans at avoparcinexposed farms. Microbial Drug Research 4, 313-318.

Smith HW (1967) The effect of the use of antibacterial drugs, particularly as food additives, on the emergence of drugresistant strains of bacteria in animals. New Zealand Veterinary Journal 15, 153-166.

Smith HW (1973) Effect of prohibition of the use of tetracyclines in animal feeds on tetracycline resistance of faecal E. coli of pigs. Nature 243, 237-238.

Smith KE, Besser JM, Hedberg CW, Leaner FT, Bender JB, Wickland JH, Johnson BP, Moore KA \& Osterholm MT (1998) Quinolone-resistant Campylobacter jejuni infections in Minnesota. New England Journal of Medicine 340, $1525-1532$.

Stobberingh E, van den Bogaard A, London N, Driessen C, Top J \& Willems R (1999) Enterococci with glycopeptide resistance in turkeys, turkey farmers, turkey slaughterers and (sub)urban residents in the south of The Netherlands: evidence for transmission of vancomycin resistance from animals to humans? Antimicrobial Agents and Chemotherapy 43, 2215-2221. 
Stokestad ELR \& Jukes TH (1950) The multiple nature of the animal protein factor. Journal of Biological Chemistry 180, 647-654.

Sunde M, Fossum K, Sloberg A \& Sorum H (1998) Antibiotic resistance in Escherichia coli of the normal intestinal flora of swine. Microbial Drug Resistance 4, 289-299.

Sundlof S, Cooper J \& Miller M (1997) Safety requirements for antimicrobial drug products used in food producing animals. In The Medical Impact of the Use of Antimicrobials in Food Animals, section 2.2.3. Geneva: WHO.

Swann MM (1969) Use of Antibiotics in Animal Husbandry and Veterinary Medicine. UK Joint Committee Report London: H.M. Stationery Office.

Taylor DJ (1999) The pros and cons of antimicrobial use in animal husbandry. Baillière's Clinical Infectious Diseases 5, 269-287.

Thomke S \& Elwinger K (1997) Growth and Feed Efficiency Responses to Antibiotic Growth Promotants in Pigs and Poultry. Report to the Commission on Antimicrobial Feed Additives. Uppsala, Sweden: Swedish University \& Agricultural Science.

Threlfall EJ (1992) Antibiotic and the selection of food-borne pathogens. Journal of Applied Microbiology 83, 96S$102 \mathrm{~S}$.

Threlfall EJ, Rowe B \& Ward LR (1993) A comparison of multiple drug resistance in salmonellas from humans and food animals in England and Wales, 1981 and 1990. Epidemiology and Infection 111, 189-197.

Tsinas AC, Kyriakis SC, Lekkas S, Sarris K, Bourtzi-Hatzopoulou E \& Saoulidis K (1998) Control of proliferative enteropathy in growing/fattening pigs using growth promoters. Zentralblatt für Veterinarmedizin 45B, 115-127.

Turnidge J (1998) What can be done about resistance to antibiotics? British Medical Journal 317, 645-647.

van den Bogaard AE, Jensen L \& Stobberingh EE (1997) Vancomycin-resistant enterococci in turkeys and farmers. New England Journal of Medicine 337, 1558-1559.

van den Bogaard AE \& Stobberingh EE (1999) Antibiotic usage in animals. Drugs 58, 589-607.

van den Braak N, van Belkum A, van Keulen M, Vliegenthart J, Verbrugh HA \& Endtz HP (1998) Molecular characterisation of vancomycin-resistant enterococci from hospitalised patients and poultry products in The Netherlands. Journal of Clinical Microbiology 36, 1927-1932.

van der Wolf PJ, Bongers JH, Elbers AR, Franssen FM, Hunneman WA, van Exsel AC \& Tielen MJ (1999) Salmonella infections in finishing pigs in the The Netherlands: bacteriological herd prevalence, serogroup and antibiotic resistance of isolates and risk factors for infection. Veterinary Microbiology 67, 263-275.

Velazquez JB, Jiminez A, Chomon B \& Villa TG (1995) Incidence and transmission of antibiotic resistance in Campylobacter jejuni and Campylobacter coli. Journal of Antimicrobial Chemotherapy 35, 173-178.

Verbeke W \& Viaene J (1996) Environmental Impact of Using Feed Additives. Report. Ghent, Belgium: University of Ghent.

Viaene J (1997a) The Swedish Animals Production System: Could it be Applied across the European Union? Report. Ghent, Belgium: University of Ghent.

Viaene J (1997b) Antimicrobials ban hits Swedish Production. Feed Mix 5, 27-29.

Viaene J (1997c) Swedish questioning EU animal production models. Feedstuffs 16 June issue.

Wall PG, Morgan D, Lamden K, Griffin M, Threlfall EJ, Ward R \& Rowe B (1995) Transmission of multi-resistant strains of Salmonella typhimurium from cattle to man. Veterinary Record 136, 591-592.

Wegener HC (1998) Historical yearly usage of glycopeptide for animals and humans: the American-European paradox revisited. Antimicrobial Agents and Chemotherapy 42, 3040.

Wegener HC, Aarestrup FM, Jensen LB, Hammerum AM \& Bager F (1999) Use of antimicrobial growth promoters in food animals and Enterococcus faecium resistance to therapeutic antimicrobial drugs in Europe. Emerging Infectious Diseases 5, 329-335.

Wegener HC, Madsen M, Nielsen N \& Aarestrup FM (1997) Isolation of vancomycin resistant Enterococcus faecium from food. International Journal of Food Microbiology 35, 57-66.

Werner G, Klare I \& Witte W (1998) Association between quinupristin/dalfopristin resistance in glycopeptide-resistant Enterococcus faecium and the use of additives in animal feed. European Journal of Clinical Microbiology and Infectious Diseases 17, 401-402.

Wicker DL, Isgrigg WN \& Trammel JH (1977) The control and prevention of necrotic enteritis in broilers with zinc bacitracin. Poultry Science 56, 1229-1231.

Wierup M (1997) Ten years without antibiotic growth promoters - results from Sweden with special reference to production results, alternative disease preventive methods and the usage of antibacterial drugs. In The Medical Impact of the Use of Antimicrobials in Food Animals, section 5.1.b. Geneva: WHO.

Williams RJ \& Heymann DL (1998) Containment of antibiotic resistance. Science 279, 1153-1154.

Williams Smith H (1980) Antibiotic-resistant Escherichia coli in market pigs in 1956-1979: the emergence of organisms with plasmid-borne trimethoprim resistance. Journal of Hygiene (London) 84, 467-477.

Witte W (1997) Impact of antibiotic use in animal feeding on resistance of bacterial pathogens in humans (with Discussion). Ciba Foundation Symposium 207, 61-75.

Witte W (1998) Medical consequences of antibiotic use in agriculture. Science 279, 996-997.

Woodford N (1998) Glycopeptide-resistant enterococci: a decade of experience. Journal of Medical Microbiology 47, $849-862$

Woodford N, Warner M \& Aucken HM (2000) Vancomycin resistance among epidemic strains of methicillin-resistant Staphylococcus aureus in England and Wales. Journal of Antimicrobial Chemotherapy 45, 258-259. 
Woodward KN (1991) Hypersensitivity in humans and exposure to veterinary drugs. Veterinary and Human Toxicology 33, $168-172$.

World Health Organization (1997) The Medical Impact of the Use of Antimicrobials in Food Animals. Geneva: WHO. World Health Organization (1998) The Use of Quinolones in Food Animals and Potential Impact on Human Health. Geneva: WHO.

World Health Organization (1999) Informal Information Meeting on Antimicrobial Resistance Surveillance in Foodborne Pathogens. Geneva: WHO.

Wray C, Hedges R, Shannon KP \& Bradley DE (1986) Apramycin and gentamicin resistance in Escherichia coli and salmonellas isolated from farm animals. Journal of Hygiene (London) 97, 445-456.

Wray C, McLaren IM \& Beedell YE (1993a) Bacterial resistance monitoring of salmonella isolated from animals; national experience of surveillance schemes in the United Kingdom. Veterinary Microbiology 35, 313-319.

Wray C, McLaren IM \& Carroll PJ (1993b) Escherichia coli isolated from animals in England and Wales between 1986 and 1991. Veterinary Record 133, 439-442.

Young HK (1993) Antimicrobial resistance spread in aquatic environments. Journal of Antimicrobial Chemotherapy 31, 627-635. 